\title{
PID controller tuning using bacterial Quorum Sensing (QS)
}

\section{Sintonización de controlador PID utilizando Quorum Sensing (QS) bacterial}

\author{
Fredy Hernán Martínez Sarmiento ${ }^{1}$, Diego Mauricio Acero Soto ${ }^{2}$ (D)
}

Fecha de recepción: 20 Septiembre 2019 Fecha de aceptación: 05 de Febrero de 2020

Cómo citar: Martínez-Sarmiento., F.H., y Acero-Soto., D.M. (2020). PID controller tuning using bacterial Quorum Sensing (QS). Tecnura, 24(64) 13-22. https://doi.org/10.14483/22487638.16530

\section{RESUMEN}

Contexto: Los controladores PID son ampliamente utilizados para operar motores AC debido a su simplicidad y fácil implementación. Sin embargo, la sintonización de sus parámetros en busca de un esquema óptimo puede ser compleja debido a que requiere sintonización manual mediante prueba y error. El objetivo de esta investigación es implementar un esquema de ajuste optimizado mediante una búsqueda basada en el comportamiento idealizado de una comunidad de bacterias y su detección de quórum (Quorum Sensing, QS).

Metodología: Se plantea el modelo del sistema en lazo cerrado con control PID considerando las perturbaciones con el objetivo de sintonizar un controlador resistente a ellas. La respuesta del modelo se calcula mediante una búsqueda que imita un modelo simplificado de comportamiento bacterial. El esquema utiliza el ITSE (Integral Time Squared Error) como indice de desempeño.

Resultados: La sintonización mediante el esquema propuesto fue evaluada mediante simulación y comparada con sintonizaciones del mismo modelo realizadas mediante Root Locus y Algoritmos Genéticos (GA). Los resultados mostraron una respuesta satisfactoria frente a los criterios de diseño.

Conclusiones: Los controladores PID siguen siendo hoy en día herramientas básicas de control industrial, particularmente importantes en el manejo de motores. El desempeño de estos controles depende fundamentalmente del diseño de su ganancia. En el caso de plantas complejas se requiere de herramientas

\footnotetext{
Ph.D en Ingeniería Sistemas y Computación, Especialista en Gestión de Proyectos de Ingeniería, Ingeniero Electricista. Profesor en la Universidad Distrital Francisco José de Caldas. Bogotá D.C., Colombia. Contacto: fhmartinezs@udistrital.edu.co ORCID: https://orcid.org/0000-0002-7258-3909

Ingeniero Electrónico. Profesor en la Universidad Pedagógica Nacional. Bogotá D.C., Colombia. Contacto: dacero@pedagogica.edu.co ORCID: https://orcid.org/0000-0002-9384-3140
} 
adicionales que faciliten la sintonización del PID. Nosotros proponemos un esquema de sintonización inteligente y bio-inspirado que demuestra un alto desempeño en pruebas de laboratorio.

Financiamiento: Universidad Distrital Francisco José de Caldas a través del proyecto 1-72-578-18.

Palabras clave: bio-inspirado; control; lazo cerrado; PID; Quorum Sensing; sintonización.

\section{ABSTRACT}

Objective: PID controllers are widely used to operate AC motors due to their simplicity and easy implementation. However, adjusting its parameters in search of an optimal scheme can be complex because it requires manual tuning by trial and error. This research aims to implement an optimized tuning scheme through a search based on the idealized behavior of a community of bacteria and its Quorum Sensing (QS).

Methodology: A closed-loop system model with PID control considering disturbances is proposed in order to tune a disturbance-resistant controller. The response of the model is calculated using a search that mimics a simplified model of bacterial behavior. The scheme uses ITSE (Integral Time Squared Error) as the performance index.

Results: The tuning resulting from the proposed scheme was evaluated by simulation and compared with tunings of the same model made by Root Locus and Genetic Algorithms (GA). The results showed a satisfactory response according the design criteria.

Conclusions: Nowadays, PID controllers are still basic industrial control tools, particularly important in motor operation. The performance of these controls depends fundamentally on the design of their gain. In the case of complex plants, additional tools are required to facilitate PID tuning. We propose an intelligent and bio-inspired tuning scheme that demonstrates high performance in laboratory tests.

Financing: University Francisco José de Caldas through the project 1-72-578-18.

Keywords: bio-inspired; closed loop; control; PID; Quorum Sensing; tuning.

\section{INTRODUCTION}

Control theory has come a long way in schemes such a Model Predictive Control (MPC), Internal Model Control (IMC), and Sliding Mode Control (SMC). Many of the specialized control design works use any of these schemes, or combinations of them (Chen, Zeng, and Xie, 2018; Wang, Mihalec, Gong, Pompili, and Yi, 2018). Still, in many everyday industrial applications, it is normal to find PID (Proportional, Integral, Derivative) control schemes (Armin, Roy, Sarkar, and Das, 2018; Wang, Wang, Yun, and Wang, 2018). This is because these con- trollers have a very straightforward and intuitive structure, besides working well for systems with second-order behavior, with a relatively simple principle of adjustment (Arbulú, Martínez and Montiel, 2015).

While their structure replicates secondorder linear compensation, PID controllers are also used in higher-order, non-linear, industrial systems (Jayaraman, Vijayakumar, Nandagopal, and Rameshkumar, 2018; Patil, Waghmare, and Uplane, 2019). With good tuning, these schemes can provide robust and stable behavior, and these are systems that can be implemented both analogically and digitally (Sanghavi, Tejaswini, and Venkateshappa, 2019). They 
can even be tuned on-line without stopping the process if the control criteria over the plant changes. Tuning corresponds to a search problem matching a performance function. Conventional tuning strategies are based on the frequency response of the plant, but they are rarely used in real applications. For example, this is the case of the ZieglerNichols method, whose tuning rule can produce an oscillating response system if the plant is non-linear (Tasoren, Orenbas, and Sahin, 2018).

Many strategies for tuning PID controller parameters for open-loop systems have been documented (Vanavil, Krishna, and Seshagiri, 2015). Several strategies are based on direct synthesis (DS), taking advantage of the knowledge of the plant model and its desired behavior (Chanti, Santosh, and Padma, 2017; Ravi and Padma, 2018). In general, these strategies raise the characteristic equation of the process, including the PID control block, and compare it to the desired characteristic equation in the closed-loop. Then, it is possible to mathematically define the parameters of the PID block.

Therefore, since tuning is a search problem, many tuning strategies based on uninformed search algorithms such as Genetic Algorithms (GA) (Febina, Sunil, and Jacob, 2018), Particle Swarm Optimization (PSO) (Ramirez, López, and noz, 2018), and Ant Colony Optimization (ACO) (Jagatheesan, Anand, Dey, and Ashour, 2018) have also been proposed. Other randomized search strategies inspired by collective behaviors observed in nature have also been considered (Ali, Afandi, Parwati, Hidayat, and Hasyim, 2019; Ataslar-Ayyıldız and Karahan, 2018). These strategies are based on evaluating the performance of possible solutions to the problem (e.g. a set of parameters that can be PID gain values) and several values according to the behavior of some performance function (Abhishek, 2015). This being applied to a set of solutions uniformly distributed in the search space guarantees to find a pseudo-optimal solution faster than the traditional gradientbased algorithm.

The search problem becomes more complex when the plant has a changing dynamic; for example, when there are disturbances in the system (Habibi, Rahimi, and Howard, 2018; Hettrick and Todd, 2019). In these cases, the tuning strategies include automatic tuning schemes, adaptive PIDs, and intelligent systems. In such cases the tuning is dynamic, and they consider some kind of information about the changes in the process as part of the adjustment.

This research proposes an intelligent tuning strategy of a PID controller for a system with disturbances based on the idealized behavior of bacteria, including their QS to reduce the convergence time (Martínez, Rendón, and Arbulú, 2018; Jacinto, Giral, and Martinez, 2016). The strategy is implemented and evaluated by simulation.

The article is organized as follows. Section 2 formulates the problem and presents some preliminary concepts, the functional profile, and other design considerations. Section 3 details the design of the system, including the selection criteria and the final specifications that were adopted. Section 4 presents the performance evaluation observed through simulation, and Section 5 concludes the article. 


\section{PROBLEM STATEMENT}

The model of the system under study with the proposed control scheme is shown in Figure $i$.
In Figure $1 \mathrm{~K}(\mathrm{~s})$ is the transfer function of the PID controller, G(s) is the transfer function of the plant, $r(t)$ is the reference signal for controlling the plant, $\mathrm{e}(\mathrm{t})$ is the system error, $\mathrm{u}(\mathrm{t})$ is the controlled input, $\mathrm{n}(\mathrm{t})$ is the disturbance, $\mathrm{W}(\mathrm{s})$ is the disturbance dynamics, and $y(\mathrm{t})$ is

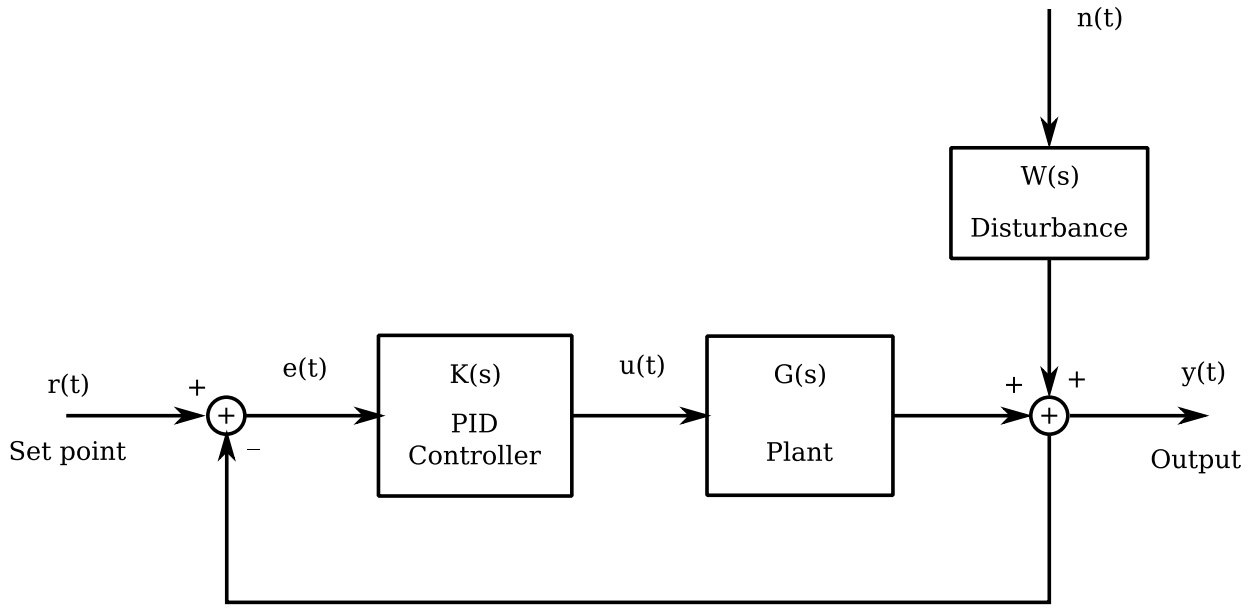

Figure 1.Control system with PID Controller and disturbance Fuente: Own production

the output signal. According to Figure 1 (Equation1):

$$
K(s)=\frac{U(s)}{E(s)}=k_{p}\left[1+\frac{1}{s T_{i}}+s T_{d}\right]
$$

Where the new constants correspond to the tuning of the PID controller. These can be rewritten vectorially as (Equation 2):

$$
\boldsymbol{C}=\left[\begin{array}{l}
c_{1} \\
c_{2} \\
c_{3}
\end{array}\right] \quad / c_{1}=k_{p}, c_{2}=T_{i} \text {, and } c_{3}=T_{d}
$$

Also, from Figure 1 (Equation 3):

$Y(s)=\left[\frac{G(s) K(s)}{1+G(s) K(s)}\right] R(s)+W(s) N(s)$

The tuning process consists of finding the vector $\mathrm{C}$ so that the performance function (a function that evaluates the steady-state error) is minimal. As a search scheme, we propose a simplified bac- terial interaction model that includes QS. Our model of bacterial interaction is based on the cell-to-cell communication. We have technically called this process local communication between artificial agents that emulate biological bacteria. Biological bacteria read local information from the identification of chemical elements in the environment and their concentration densities (Martínez, Hernández, and Acero, 2017). The QS follows the principles of this local communication scheme, with the particular characteristic that it allows coordinating the collective behavior of the bacterial population from certain specific readings. For instance, one of these readings can determine that the bacterial population is high and can activate a collective attack mechanism on the host environment (Figure 2). Bacteria deposit chemical information in the environment, and when the concentration is elevated they decode an attack action 
written in their genetic code. It is possible to imitate this behavior in artificial agents, making bacteria move to steady-state zones (possible solutions to the problem) that they find attractive (as if they were looking for food) guided by the performance function of the problem. When the number of agents in a state-space zone exceeds a quorum threshold T, the QS is activated making this zone more attractive. The point in the state space

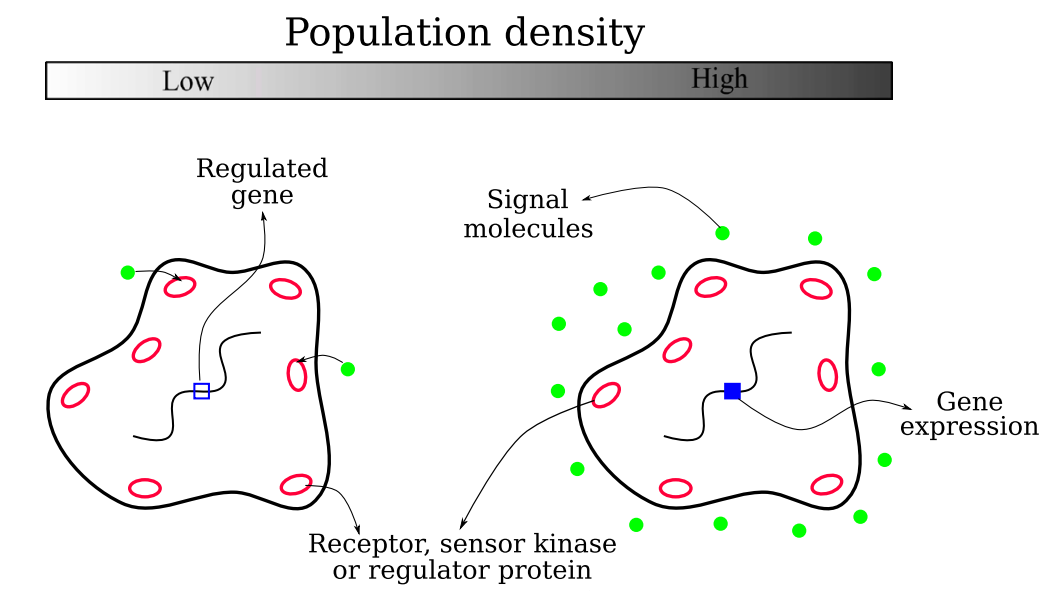

Harmless bacterium

Virulent bacterium

Figure 2. Bacterial QS.

Fuente: Own production

where the greatest number of individuals are grouped corresponds to the optimal solution of the problem.

\section{METHODOLOGY}

The design restriction for the model in

Figure 1 is (Equation 4):

$$
\max _{n(t)} \frac{\|Y\|}{\|n\|}=\left\|\frac{W(s)}{1+K(s) G(s)}\right\|_{\infty}<\delta
$$

Where $\|\cdot\|_{\infty}$ is the $H_{\infty}$-norm and $\delta<1$ is a constant that defines the desired rejection rate. Since (Equation 5):

$\|G(s)\|_{\infty}=\max _{\omega \in[0, \infty)}|G(j \omega)|$

Then the restriction for resistance to disturbance is given by (Equation 6):

$$
\begin{aligned}
\left\|\frac{W(s)}{1+K(s) G(s)}\right\|_{\infty} & =\max _{\omega \in[0, \infty)} \sqrt{\frac{W(j \omega) W(-j \omega)}{1+K(j \omega) G(j \omega) K(-j \omega) G(-j \omega)}}=\max _{\omega \in[0, \infty)} \sqrt{\sigma(\omega)} \\
<\delta &
\end{aligned}
$$

As the performance function we select the Integral Time Squared Error (ITSE) (Equation 7):

$$
\text { ITSE }=\int_{0}^{\infty} t e^{2}(t) d t
$$

This error function was selected because it includes time in its structure, which increases the effect on long-lasting errors, thus ensuring a small settling time. The structure of $e(t)$ implicitly contains the parameters of both the controller and the plant; therefore, the performance function must be minimized by tun ing vector $C$. The proposed search algorithm based on bacterial behavior has the structure shown in Figure 3. A population of $n$ bacteria is randomly 
established inthe state space of possible values of vector $C$, whose spatial position is defined by three coordinates. For example, for bacteria $\boldsymbol{i}$ we have $V_{i}\left(c_{1 i}, c_{2 i}, c_{3 i}\right)$ Each bacterium evaluates the performance of its current position through the performance function and the signal deposited in the medium by other bacteria and places a signal in the environment according to the result. Consistent with the performance value, the bacterium makes the decision to either continue exploring the environment or maintaining its position.

Depending on the signal concentration in the local environment, a bacterium evaluates the number of neighboring bacteria in the same position (within a radius of neighborhood), and if the concentration exceeds the threshold of quorum $T$, the QS is activated. When the QS is activated, the bacteria place a second signal in the environment that increases the performance value of its position, attracting other bacteria more quickly. The coordinates of the meeting point of the bacteria correspond to the value of vector $C$.

In the Explorer behavior, the agent moves in the state space to find other areas of interest. In general, Virulent behavior is only activated by population density, which only happens if the area is attractive for many bacteria. The movement involves changing the value of the constants of the PID controller (tuning) and is done by trying to minimize the error (increasing the performance value). The region with the highest concentration of bacteria will be the optimal solution.

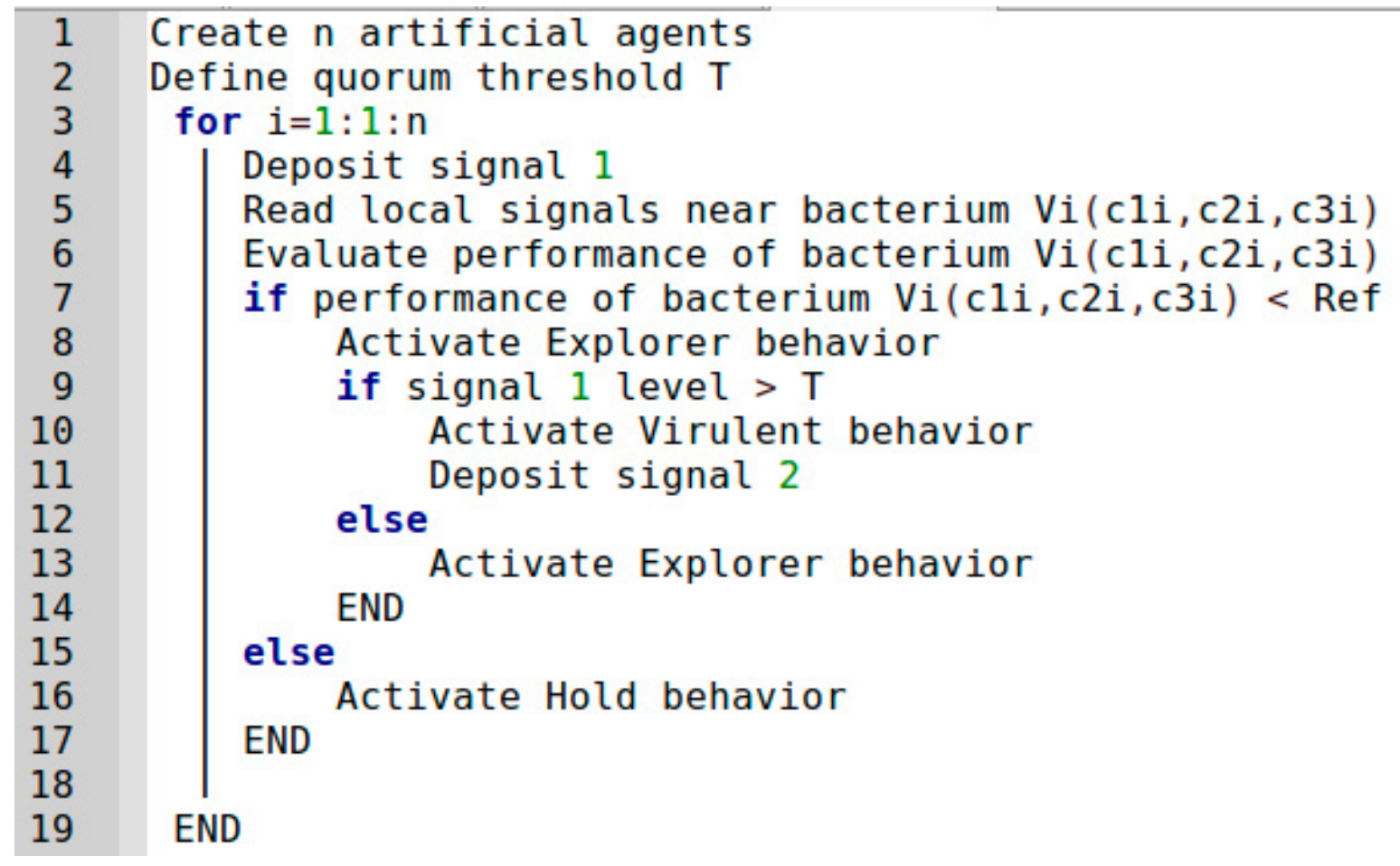

Figure 3. Pseudo code of bacterial algorithm for optimization of the PID controller.

Fuente: Own production 


\section{RESULTS}

We used the second-order linear shape shown in Eq. 8 as a model of the plant:

$$
G(s)=\frac{0.8}{0.5 s^{2}+s}
$$

We tested different types of disturbances with $W(s)=\frac{1}{s+1}$. For example, for a sinusoidal perturbation the bacterial scheme with QS determined the following values:

- $k_{p}=28.541$

- $T_{i}=0.262$

- $T_{d}=28.898$

- $\operatorname{ITSE}=0.778 \times 10^{-3}$

Figure 4. shows the behavior of this design. Image 4(a) shows the step response of the system without applying disturbances, while

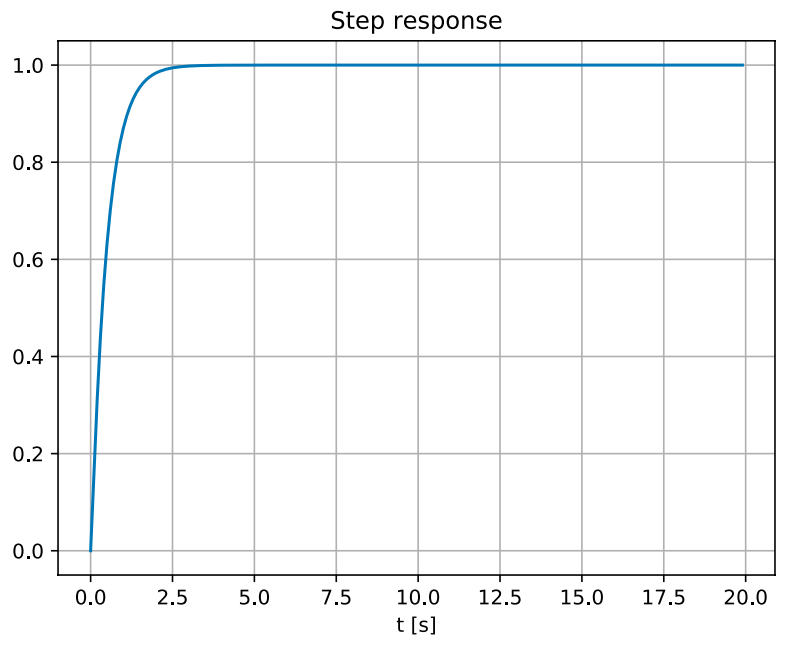

(a)
Image 4(b) shows the same behavior with disturbance applied. In both cases, there is a short rise time and scanty steady-state error. Image 4(b) also shows how the control responds positively to the disturbance.

\section{CONCLUSIONS}

In this paper, we propose a PID controller tuning scheme for plants with disturbances using a parameter-search method based on bacterial interaction with QS. The scheme poses the constraints of PID control design and a performance function based on ITSE. Through basic rules of interaction on a community of agents designed on the state space of the solution, we make interact the bacteria until they gather at the points of greater performance. QS is activated at these points, which accelerates the convergence of the algorithm. The intelligent tuning scheme converged quickly at a very low computational cost. In addition, the tuning parameters found proved to satisfy the design conditions.

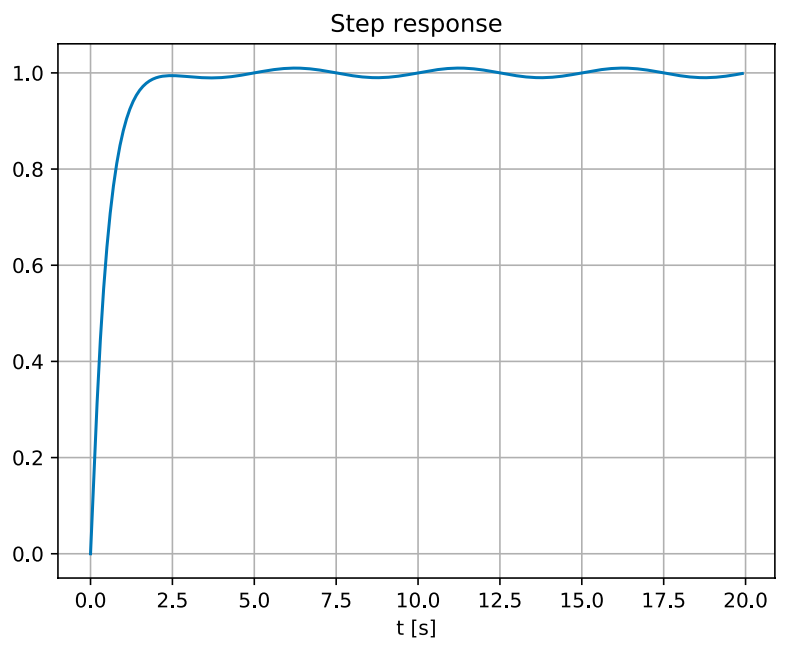

(b)

Figure 4. Step response of the PID controller tuned with the bacterial scheme. (a) No disturbance. (b) With sinusoidal perturbations.

Fuente: Own production 


\section{ACKNOWLEDGMENTS}

This work was supported by the University Francisco José de Caldas through the project 1-72-578-18. The views expressed in this paper are not necessarily endorsed by the University.

The authors thank the research group ARMOS for the evaluation carried out on prototypes of ideas and strategies.

\section{REFERENCES}

Abhishek, V. (2015). Stability analysis and design of a I gorith mi c tuned PID controller for bio-reactor. International Journal of Research in Engineering and Technology, 4(1), 28-35. https://doi. org/10.15623/ijret.2015.0404006

Ali, M., Afandi, A., Parwati, A., Hidayat, R., and Hasyim, C. (2019). Design of water level control systems using PID and ANFIS based on firefly algorithm. Journal of Electrical Engineering, Mechatronic and Computer Science, 2(1), 9-14. https://doi. org/10.26905/jeemecs.v2i1.2804

Arbulú, M., Martínez, F., and Montiel, A. (2015). Metodología para el uso de la técnica de localización de raíces en la planeación de rutas para robots móviles. Tecnura, 19(46), 4964. https://doi.org/10.14483/udistrital.jour.tecnura.2015.4.a04

Armin, M., Roy, P., Sarkar, S., and Das, S. (2018). LMI-based robust PID controller design for voltage control of islanded microgrid. Asian Journal of Control, 20(5), 2014-2025. https://doi.org/10.1002/asjc.1710
Ataslar-Ayyıldız, B., and Karahan, O. (2018). Tuning of fractional order PID controller using cs algorithm for trajectory tracking control. In 6 th international conference on control engineering information technology (CEIT 2018) (p. 1-6). https://doi.org/10.1109/ CEIT.2018.8751895

Chanti, D., Santosh, D., and Padma, R. (2017). Tuning of PID controllers for unstable systems using direct synthesis method. Indian Chemical Engineer, 59(3), 215-241. https:// doi.org/10.1080/00194506.2016.1 255570

Chen, M.-R., Zeng, G.-Q., and Xie, X.Q. (2018). Population extremal optimization-based extended distributed model predictive load frequency control of multi-area interconnected power systems. Journal of the Franklin Institute, 355(17), 82668295. https://doi.org/10.1016/j. jfranklin.2018.08.020

Febina, P., Sunil, T., and Jacob, J. (2018). GA tuned two degree of freedom PID controller for time delay systems. International Journal of Intelligent Systems Technologies and Applications, 17(1), 123 135. https://doi.org/10.1504/IJISTA.2018.10012889

Habibi, H., Rahimi, H., and Howard, I. (2018). Adaptive PID control of wind turbines for power regulation with unknown control direction and actuator faults. IEEE Access, 6(1), 37464 37479. https://doi.org/10.1109/ACCESS.2018.2853090

Hettrick, H., and Todd, J. (2019). Inflight adaptive PID sliding mode 
position and attitude controller. In IEEE aerospace conference (p. 1-9). https://doi.org/10.1109/ AERO.2019.8741991

Jacinto, E., Giral, M., and Martínez, F. (2016). Multi-agent navigation model based on bacterial quorum sensing. Tecnura, 20(47), 29-38. https:// doi.org/10.14483/udistrital.jour.tecnura.2016.1.a02

Jagatheesan, K., Anand, B., Dey, N., and Ashour, A. (2018). Effect of SMES unit in AGC of an interconnected multi-area thermal power system with aco-tuned PID controller. In (p. 164-185). IGI Global. https://doi. org/10.4018/978-1-5225-4151-6. ch007

Jayaraman, L., Vijayakumar, K., Nandagopal, V., and Rameshkumar, K. (2018). Implementation of ILC based gain scheduled PID controller for non linear spherical tank level process. International Journal of Pure and Applied Mathematics, 118(18), 4637-4644.

Martínez, F., Hernández, C., and Acero, D. (2017). Segmentación de imagen por color basado en quorum sensing bacterial. Tecnura, 20(2016), 55-63.

Martínez, F., Rendón, A., and Arbulú, M. (2018). An algorithm based on the bacterial swarm and its application in autonomous navigation problems. Lecture Notes in Computer Science, 10941(1), 304-313. https:// doi.org/10.1007/978-3-319-938158_30

Patil, B., Waghmare, L., and Uplane, M. (2019). Discrete sliding mode controller action with pid sliding surface for non linear plant along with changing set point. In 3 rd international conference on computing methodologies and communication (ICCMC 2019) (p. 177-181). https://doi.org/10.1109/ ICCMC.2019.8819864

Ramirez, J., López, J., and noz, N. M. (2018). Particle swarm metaheuristic applied to the optimization of a PID controller. Contemporary Engineering Sciences, 11(67), 33333342. https://doi.org/10.12988/ ces.2018.87350

Ravi, C., and Padma, R. (2018). Design of PID controllers for unstable systems using multiple dominant poleplacement method. Indian Chemical Engineer, 60(4), 356-370. https:// doi.org/10.1080/00194506.2017.1 363673

Sanghavi, B., Tejaswini, C., and Venkateshappa, V. (2019). DC/DC boost converter using DSP controller for fuel cell. Perspectives in Communication, Embedded-System and Signal-Processing, 2(10), 248-251.

Tasoren, A., Orenbas, H., and Sahin, S. (2018). Analyze and comparison of different PID tuning methods on a brushless DC motor using Atmega328 based microcontroller unit. In 6th international conference on control engineering information technology (CEIT 2018) (p. 1-4). http s:// doi.org/10.1109/CEIT.2018.8751768

Vanavil, B., Krishna, K., and Seshagiri, A. (2015). Improved PID controller design for unstable time delay processes based on direct synthesis method and maximum sensitivity. International Journal of Systems Science, 46(8), 1349-1366. 
Wang, B., Mihalec, M., Gong, Y., Pompili, D., and $Y i$, J. (2018). Disturbance observer-based motion control of small autonomous underwater vehicles. In Dynamic systems and control conference (ASME 2018) (p. 1-8).

https://doi.org/10.1115/DSCC20189200

Wang, Z., Wang, L., Yun, Z., and Wang, J. (2018). Temperature control based on fuzzy-PID algorithm for the blackbody radiation source. In IEEE international conference on mechatronics and automation (ICMA 2018) (p. 797-802). https://doi.org/10.1109/ ICMA.2018.8484315

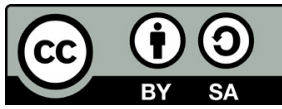

